\title{
UVR induce optical changes and phosphorous release of lake water and macrophyte leachates in shallow Andean lakes
}

\author{
Marcela BASTIDAS NAVARRO* and Beatriz MODENUTTI \\ INIBIOMA (CONICET) - UNC Laboratorio de Limnología, Quintral 1250, 8400 Bariloche, Argentina \\ *e-mail corresponding author: bastidas@crub.uncoma.edu.ar
}

\begin{abstract}
We carried out laboratory experiments in order to study the effect of ultraviolet radiation (UVR) on optical features and phosphorous release of Dissolved Organic Mater (DOM) from lake water and macrophyte leachates. Lake water samples were obtained from lakes Escondido and El Trébol, and macrophytes (Potamogeton linguatus and Schoenoplectus californicus) from their littoral zones. After UVR exposure, DOM from lake El Trébol seemed to react more quickly than that from Lake Escondido and this seems to be related with the degree of lability or aromaticity in the DOM bulk of each lake. Leachates from both macrophytes showed different absorbance spectra with differences in photochemical transformations after UVR exposure: S. californicus leachates exhibited the highest photodegradation. A significant Soluble Reactive Phosphorus (SRP) release was observed in lake water after UVR exposure. Lake El Trébol showed the highest SRP concentrations, suggesting that the release of orthophosphate was favored by low molecular weight DOM. P. linguatus leachates have more dissolved phosphorus content than $\mathrm{S}$. californicus ones and after UVR exposure, P. linguatus leachate did not react to UVR while S. californicus exhibited a decrease in SRP. However both macrophyte leachates showed the higher P release in darkness. The obtained results indicated that macrophyte leachates could contribute significantly to changes in the optical characteristics and in the nutrient content in shallow Andean lakes. An increasing input of $\mathrm{P}$. linguatus leachates would produce DOM of high molecular size and a higher P release than $\mathrm{S}$. californicus.
\end{abstract}

Key words: UV radiation (UVR), dissolved organic matter (DOM), macrophyte leachates, phosphorous release, shallow Andean-Lakes

\section{INTRODUCTION}

Dissolved organic matter (DOM) represents a significant component absorbing solar radiation in aquatic ecosystems, particularly in the ultraviolet region of the light spectrum (290 - $400 \mathrm{~nm}$ ) (Morris et al. 1995; Osburn et al. 2001; Schindler \& Curtis 1997). This energy absorption may lead to a variety of photochemical processes, including the photodegradation of DOM that could be related to changes in spectral and molecular properties (Bertilsson \& Tranvik 2000; Farjalla et al. 2001; Helms et al. 2008). Additionally, a particular interest in these reactions rises from the increment of UVR recorded in Earth surface caused by the reduction in the stratospheric ozone layer (Osburn et al. 2001; Zepp et al. 2003; Vernet 2006).

In freshwater ecosystems, the DOM concentration is higher relative to marine environment, as a result of the macrophyte presence (Wetzel 2001; Osborne \& Kovacic 2007). Macrophytes constitute an important carbon source for the total content of DOM in lakes (Wetzel 2001); however, it is still poorly known the potential contribution to lake nutrient content of leachates from different macrophyte species, and its overall influence on optical features of lake water. Macrophytes release DOM synthesized during photosynthesis or through leaching of aged and dead tissues (Bertilsson \& Jones 2003). In particular, UVR increases macrophyte degradation and leachate production (Mans et al. 1998; Ane- sio et al. 1999), that may result in an important source of essential nutrients such as nitrogen and phosphorus (Lewis 2002; Qualls \& Richardson 2003). Therefore, chemical features of bulk DOM affect water chemistry controlling the availability and lability of nutrients, metals and toxic substances (Strober et al. 1995). Most DOM present in aquatic environments is constituted by humic substances, which are the main binding agent of $\mathrm{Fe}$ and $\mathrm{P}$ (in the orthophosphate, $\mathrm{PO}_{4}^{-3}$ form) (Maranger \& Pullin 2003). UVR photoreduction and dark reduction are two important physico-chemical mecanisms involved in the reduction of $\mathrm{Fe}$ (III) asociated to DOM. These reductions imply the release of $\mathrm{PO}_{4}^{-3}$, generally associated to the Fe (III) form (Maranger \& Pullin 2003). Although its importance, the release of nutrients from macrophyte leachates has received little attention (Osborne \& Kovacic 2007) and there are few studies regarding the effect of UVR and darkness as factors contributing to phosphorus availability in freshwater environments. UVR can also affect alkaline phosphatase activity that could contribute to microscale variations in nutrient availability and community composition near lake surface (Tanks et al. 2005).

Andean shallow lakes from North Patagonia $\left(41^{\circ} \mathrm{S}\right.$ $71^{\circ} \mathrm{W}$ ) are oligotrophic environments (Rogora et al. 2008) with comparatively higher DOM content than the deeper lakes of this region (Morris et al. 1995). A previous study has shown that the increase in DOM photobleaching in shallow Andean lakes was related mainly 
to UV-A radiation (Osburn et al. 2001). Moreover, Zagarese et al. (2001) demonstrated a direct relationship between solar exposure and $\mathrm{P}$ release from DOM in a shallow Andean lake. The relatively high DOM content of shallow Andean-Patagonian lakes would be related to both, the drainage area and the macrophyte presence in their littoral zone (Bastidas Navarro et al. 2009). Macrophyte leachates could be important sources of nutrients, particularly during the senescence periods in which macrophyte decomposition would generate changes in DOM quantity and quality. Since Patagonia is under the effect of the Antarctic ozone hole (Villafañe et al. 2001), DOM from lakes and leachates would be strongly affected by UVR, modifying their optical characteristics and nutrient release. The hypothesis tested is that UVR exposure will produce changes on the mean molecular weight of DOM from lake water and macrophyte leachates. This change affects the release of Soluble Reactive P (SRP). We performed laboratory experiments on the effect of UVR on lake water of two shallow lakes (Escondido and El Trébol), and on leachates from the macrophytes Schoenoplectus californicus and Potamogeton linguatus, analizing DOM optical features and SRP release.

\section{MATERIALS AND METHODS}

\subsection{Study Area and sampling}

Lakes Escondido and El Trébol are small and shallow lakes (maximum depth of 8 and $12 \mathrm{~m}$, respectively) included in the Nahuel Huapi National Park, Patagonia, Argentina, around $41^{\circ} \mathrm{S}$ and $71^{\circ} \mathrm{W}$. The climate of this region is temperate cool (mean annual temperature 8.7 ${ }^{\circ} \mathrm{C}$ ) with an annual precipitation of $1500 \mathrm{~mm}$ (Paruelo et al. 1998). The surrounding vegetation is constituted by a mixed forest of Nothofagus dombeyi (Mirb.) Blume and Austrocedrus chilensis (D. Don) Florin et Boutleje. Their littoral zones are colonized by two aquatic weeds: the emergent Schoenoplectus californicus (Meyer) Soják and the submersed Potamogeton linguatus Hangström (Bastidas Navarro et al. 2009).

Water and macrophyte leachates from these two lakes were used to carry out our experimental study. The experiments were carried out in summer (January 2007). Surface water samples were obtained with a Van Dorn bottle, distributed in different acid washed $(\mathrm{HCl})$ containers for subsequent analysis, and inmediatly carried to the laboratory. Macrophytes were sampled in the littoral zone and also carried to the laboratory in plastic containers.

\subsection{Experimental conditions}

To ensure carbon free, all glassware was previously cleaned with diluted clorhidric acid $(0.5 \mathrm{~N})$, rinsed with MilliQ water, and then combusted at $450{ }^{\circ} \mathrm{C}$ during 1 hour. Similarly, the GF/F filters (Osmonics) were precombusted at $450{ }^{\circ} \mathrm{C}$ during 1 hour.
Lake water was filtered through the precombusted $\mathrm{GF} / \mathrm{F}$ filters, and then through $0.2 \mu \mathrm{m}$ policarbonate membrane filters. Macrophyte leachates were prepared from leaves and stems from senescent plants which were rinsed with distilled water, dried at room temperature. One (1) g of each macrophyte was placed in $100 \mathrm{~mL}$ of MilliQ water and leave it at $4{ }^{\circ} \mathrm{C}$ for $48 \mathrm{~h}$ after Anesio et al. (2000). The leachate was filtered through precombusted GF/F filter and then through esteril membrane filters of $0.2 \mu \mathrm{m}$ pore size in order to eliminate any potential presence of bacteria in the samples. The filtrate was diluted with Milli-Q water to a final concentration of $3 \mathrm{mg} \mathrm{L}^{-1}$ of dissolved organic carbon (DOC).

UVR exposure was carried out in $20 \mathrm{~mL}$ quartz tubes in an incubator with controlled temperature at 20 ${ }^{\circ} \mathrm{C}$. Quartz tubes were distributed in a frame at $30 \mathrm{~cm}$ distance from the light source following Bertilsson \& Tranvik (2000). The artificial source of light consisted in two UVA-340 fluorescent tubes (Q-Panel Lab Products, Cleveland, OH, U.S.A.). The UVR spectrum of these light tubes closely resembles the solar spectrum between 280 and $350 \mathrm{~nm}$ (Shick et al. 1999). During the incubation, water received $35 \mu \mathrm{W} \mathrm{cm} \mathrm{nm}^{-1}$ of the 340 $\mathrm{nm}$ band and this irradiance level is equivalent to surface noon summer sunlight in Andean lakes.

Soluble Reactive Phosphorus (SRP) concentrations were obtained through the ascorbate-reduced molybdenum method (APHA 2005).

\subsection{Experimental design}

Optical features of lake water and macrophyte leachates after UVR exposure were studied in two experiments (Experiments 1 and 2) in order to analyze the photodegradation in two different lengths of exposure times. Experiment 1 consisted in the exposure of surface water samples from lakes Escondido and El Trébol to UVR. In Experiment 2, Potamogeton linguatus and Schoenoplectus californicus leachates from lakes Escondido and El Trébol were exposed to UVR. In both experiments, exposure was carried out in quartz tubes in three replicates, and spectrophotometric scanning $(250-790 \mathrm{~nm})$ were carried out after 5 and 10 hours of exposure.

The release of Soluble Reactive P (SRP) from lake water and macrophyte leachates exposed to different light qualities were studied through other two experiments (Experiments 3 and 4). In Experiment 3, lake surface water from lakes Escondido and El Trébol were exposed in quartz tubes to UVR and dark conditions for 5 hours. Six $20 \mathrm{~mL}$ quartz tubes were exposed to UVR (UVR Treatment), and other six tubes were wrapped with aluminium foil (DARK Treatment). At initial time and after 5 hours of exposition we measured in three tubes of each treatment SRP concentration. The remaining three tubes were used for spectrophotometric scanning analysis. In Experiment 4, we exposed to dif- 

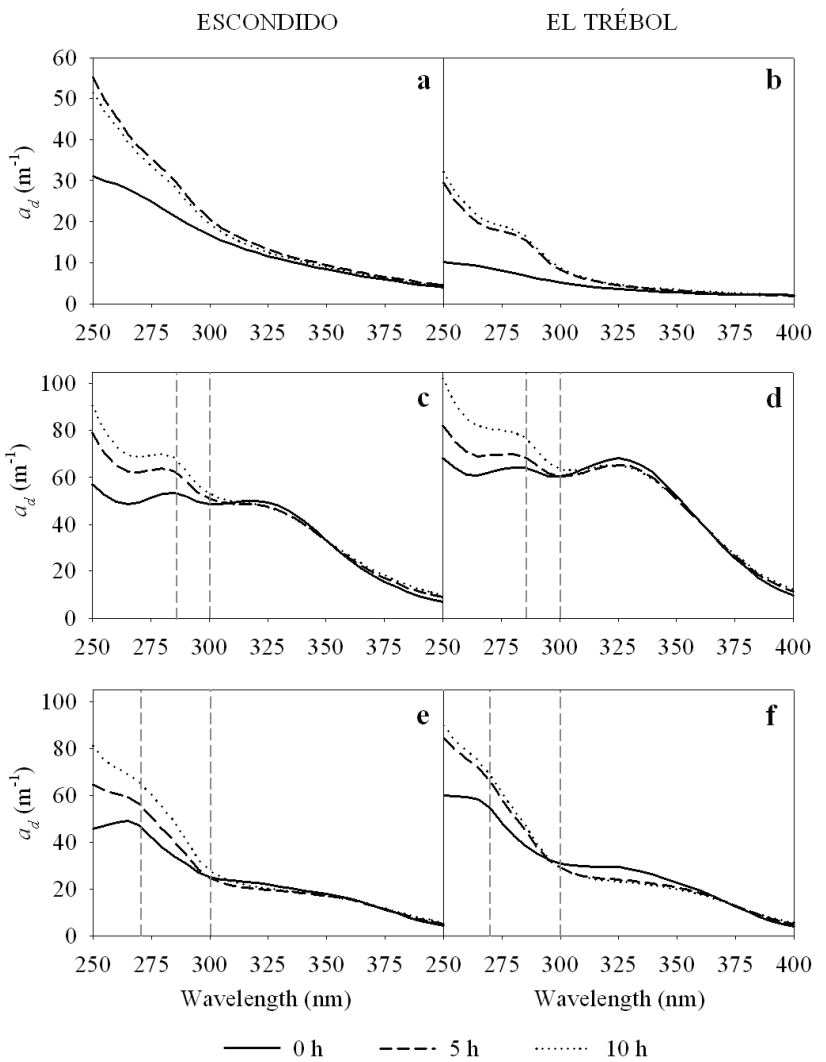

Fig. 1. Absorbance spectra after UVR exposure (0,5 and 10 hours) of lake water from lakes Escondido (a) and El Trébol (b), $P$. linguatus leachate from lakes Escondido (c) and El Trébol (d), and S. californicus leachate from lakes Escondido (e) and El Trébol (f). In (c), (d), (e) and (f), dotted lines indicate the selected range for the spectral slope calculation $\left(S_{285-300}\right.$ for $P$. linguatus, $S_{270-300}$ for $S$. californicus).

ferent light conditions (UVR and DARK) leachates of $P$. linguatus and S. californicus.

At initial and final time of each experiment, were carried out spectrophotometric scans from $250 \mathrm{~nm}$ to $790 \mathrm{~nm}$ in $10 \mathrm{~cm}$ quartz cuvette using a double beam spectrophotometer Shimadzu UV2450. In Experiments 3 and 4, also SRP concentrations were obtained at initial and final time.

\subsection{Data Analysis}

Absorbance units were converted to absorption coefficients $\left(a_{\mathrm{d}}\right)$. The ratio $a_{250}: a_{365}$ was used as a measure of the relative size of DOM molecules (Perez \& Sommaruga 2006).

The spectrum of each lake was drawn as $\operatorname{Ln}\left(a_{\mathrm{d}}\right) v s$ wavelengths. The spectral slope was determined for the UV band $\left(S_{\mathrm{UV}}\right)$ through a lineal regression of values between $290 \mathrm{~nm}$ and $400 \mathrm{~nm}$ (Green \& Blough 1994). For the macrophyte leachates experiments we calculated the spectral slope corresponding to the linear sections of the spectral curve with the higher absorbance variation. For Potamogeton linguatus, the spectral slopes were calculated between the $285-300 \mathrm{~nm}\left(S_{285-300}\right)$, whereas for Schoenoplectus californicus, the $270-300 \mathrm{~nm}\left(S_{270-300}\right)$ spectral section was used.
Differences among $S_{\mathrm{UV}}$, and $S_{285-300}$ and $S_{270-300}$ calculated for Experiments 1 and 2 (three replicates for each treatment) were compared through a Two Way ANOVA. The $a_{250}: a_{365}$ ratio from different lakes along the exposition time was also analyzed through a Two Way ANOVA using "Lake" and "Time of exposure" as factors. We choose this analysis because each tube is independent of each other during the exposure. Values of SRP concentration obtained in experiments 3 and 4 were analyzed through a Two Way ANOVA, with "Treatment", "Lake" (Experiment 3), and "Macrophyte" (Experiment 4) as factors. Post hoc comparisons were made using the Tukey Test with an overall significance level of $P=0.05$. In order to analyze if $S_{285-300}$ and $S_{270-300}$ are good estimators of photodegradation, regression analyses were performed between each wavelength range and the $a_{250}: a_{365}$ ratio. All statistical analyses were performed using SigmaStat 3.1 and Statistica 6.0.

\section{RESULTS}

\subsection{Variation in optical characteristics of lake water and leachates after UV exposure}

Spectrophotometric spectra obtained at initial time $(0 \mathrm{~h})$ for the different lakes, showed similar pattern (Fig. 1a), with maximum absorbances in the shorter wave- 
Tab. 1. Variation in $a_{250}: a_{365}$ ratio, and in the spectral slopes of the UV band $\left(S_{\mathrm{UV}}\right)$, in the different lakes at each time of exposure. Data are expressed as mean values \pm standard deviation.

\begin{tabular}{lcccc}
\hline & \multicolumn{2}{c}{ Escondido } & \multicolumn{2}{c}{ El Trébol } \\
\hline & $a_{250}: a_{365}$ & $S_{\mathrm{UV}}$ & $a_{250}: a_{365}$ & $S_{\mathrm{UV}}$ \\
$0 \mathrm{~h}$ & $4.59 \pm 0.02$ & $0.0141 \pm 0.0001$ & $7.66 \pm 0.27$ & $0.0106 \pm 0.0001$ \\
$5 \mathrm{~h}$ & $7.35 \pm 0.13$ & $0.0152 \pm 0.0002$ & $11.37 \pm 0.75$ & $0.0157 \pm 0.0009$ \\
$10 \mathrm{~h}$ & $6.76 \pm 0.68$ & $0.0151 \pm 0.0001$ & $11.34 \pm 0.49$ & $0.0150 \pm 0.0001$ \\
\hline
\end{tabular}

Tab. 2. Spectral slopes calculated between $285 \mathrm{~nm}$ and $300 \mathrm{~nm}$, in Potamogeton linguatus leachates $\left(S_{285-300}\right)$, and between $270 \mathrm{~nm}$ and $300 \mathrm{~nm}$, in Schoenoplectus californicus leachates $\left(S_{270-300}\right)$. Values are expressed as mean values \pm standard deviation.

\begin{tabular}{|c|c|c|c|c|c|}
\hline & & \multicolumn{2}{|c|}{ Potamogeton linguatus } & \multicolumn{2}{|c|}{ Schoenoplectus californicus } \\
\hline & & $a_{250}: a_{365}$ & $S_{285-300}$ & $a_{250}: a_{365}$ & $S_{270-300}$ \\
\hline \multirow{3}{*}{ Escondido } & $0 \mathrm{~h}$ & $2.691 \pm 0.009$ & $0.0064 \pm 0.0001$ & $3.149 \pm 0.016$ & $0.0213 \pm 0.0001$ \\
\hline & $5 \mathrm{~h}$ & $3.528 \pm 0.229$ & $0.0143 \pm 0.0009$ & $4.522 \pm 0.108$ & $0.0279 \pm 0.0004$ \\
\hline & $10 \mathrm{~h}$ & $3.892 \pm 0.271$ & $0.0173 \pm 0.0015$ & $5.662 \pm 0.156$ & $0.0290 \pm 0.0001$ \\
\hline \multirow{3}{*}{ El Trébol } & $0 \mathrm{~h}$ & $1.933 \pm 0.030$ & $0.0037 \pm 0.0001$ & $3.793 \pm 0.528$ & $0.0191 \pm 0.0001$ \\
\hline & $5 \mathrm{~h}$ & $2.441 \pm 0.465$ & $0.0079 \pm 0.0025$ & $5.158 \pm 0.310$ & $0.0281 \pm 0.0005$ \\
\hline & $10 \mathrm{~h}$ & $2.494 \pm 0.515$ & $0.0121 \pm 0.0004$ & $5.581 \pm 0.224$ & $0.0293 \pm 0.0004$ \\
\hline
\end{tabular}

length region. However, Lake Escondido exhibited higher absorbance coefficients in the UV range $(\sim 31.1$ $\left.\mathrm{m}^{-1}\right)$, whereas Lake El Trébol values were around 10.2 $\mathrm{m}^{-1}$. The lake water exposed for 5 and 10 hours to UVR caused, in both lakes, an increase in $a_{\mathrm{d}}$ values in the short wavelength band range (250-300 nm) (Fig. 1a, b). Moreover, we observed a significant increase in the absolute values of $S_{\mathrm{UV}}$ between $290 \mathrm{~nm}$ and $400 \mathrm{~nm}$ $\left(S_{\mathrm{UV}}\right)$ after UVR exposure (Two Way ANOVA: Time of exposure, $P<0.001$ ), without differences between 5 and 10 hours in any of the lakes (Tukey Test: Lake Escondido, $P=0.516$; Lake El Trébol, $P=0.161$ ) (Tab. 1). These results indicated an increase in the absorption in the UV range of DOM from both lake's water after the UVR exposure (Tab. 1).

The $a_{250}: a_{365}$ ratio at initial time showed significant variation between lakes (Two Way ANOVA: Lake $P$ $<0.001)$, Lake Escondido showed the lowest values (Tab. 1). After the 5 hours of UVR exposure, we observed a significant increase in this ratio in both lakes (Two Way ANOVA: Time of exposure Factor, $P$ $<0.001$; Tukey Test: for both lakes $0 \mathrm{~h} v s 5 \mathrm{~h}, P$ $<0.001$ ), indicating a decrease in the mean molecular weight of DOM. On the other hand, no significant differences were observed between $5 \mathrm{~h}$ and $10 \mathrm{~h}$ of exposure (Tukey Test: for both lakes $0 \mathrm{~h} v s 5 \mathrm{~h}, P=0.572$ ).

The absorbance spectra of leachates showed different patterns for the two macrophytes. At the initial time, a bimodal pattern was observed for $P$. linguatus leachates, with two maxima, one at $280 \mathrm{~nm}$ and another at $320 \mathrm{~nm}$ (Fig. 1c, d); while S. californicus exhibited a unimodal spectrum, with a maximum around $265 \mathrm{~nm}$ (Fig. 1e, f). After UVR exposure, we observed an attenuation of these absorbance peaks for both macrophyte species (Fig. 1c, d, e, f) and a significant increase in $S_{285-300}$ and $S_{270-300}$ (Two Way ANOVA: Time of exposure Factor for both macrophytes, $P<0.001$ ) (Tab. 2). In particular, in $P$. linguatus leachates from Lake Escondido, significant differences were observed in $S_{285-300}$ between the two exposure times (Tukey Test: in all cases $P \leq 0.003$ ). $P$. linguatus leachates from Lake El Trébol also evidenced significant differences in $S_{270-300}$ with time of exposure (Tukey Test: in all cases $P$ $\leq 0.013$ ). S. californicus leachate from both lakes showed a significant increase in $S_{285-300}$ with time of exposure (Tukey Test: in all cases $P \leq 0.009$ ) (Tab. 2). Furthermore, we observed variations in the $S_{285-300}$ and $S_{270-300}$ values analyzed for each macrophyte between both lakes (Two Way ANOVA: Lake Factor for $P$. linguatus, $P<0.001$; Lake Factor for $S$. californicus, $P=$ $0.009)$. In $P$. linguatus we observed significant differences between lakes at each time of exposure (Tukey Test: for all time levels, $P \leq 0.005)$. On the other hand, $S$. californicus evidenced significant differences between lakes only at initial time $(0 \mathrm{~h})$ (Tukey Test: $P<0.001)$.

Mean molecular weight of DOM from leachates showed a similar trend, decreasing with UVR exposure (Tab. 2). P. linguatus leachate exhibited lower molecular size than $S$. californicus all along the exposure time (Tab. 2). This pattern was observed both in Lake Escondido and Lake El Trébol; nevertheless, in the first one the difference between both macrophytes was lower.

The regression analyses between $S_{285-300}$ and $S_{270-300}$ and $a_{250}: a_{365}$ ratio for $P$. linguatus and $S$. californicus respectively, showed significant relationships (Fig. 2). In $P$. linguatus leachate from Lake Escondido, we obtained a positive correlation with $r^{2}=0.849$ ( $P$ $<0.001)$, and $r^{2}=0.815$ in Lake El Trébol $(P<0.001)$. In $S$. californicus leachate from Lake Escondido we 


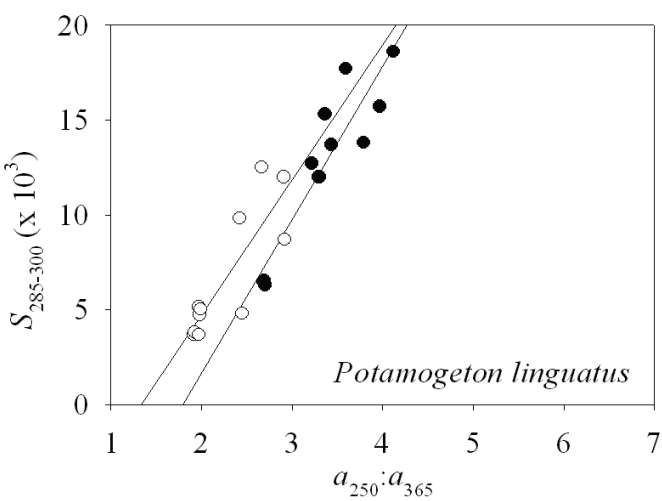

- ESCONDIDO

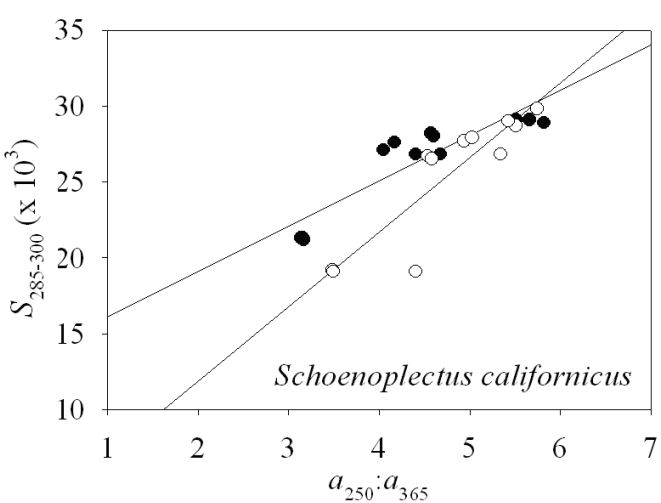

EL TRÉBOL

Fig. 2. Regression lines between $S_{285-300}$ vs $a_{250}: a_{365}$, in P. linguatus leachates, and between $S_{270-300}$ vs $a_{250}: a_{365}$ in $S$. californicus leachates.
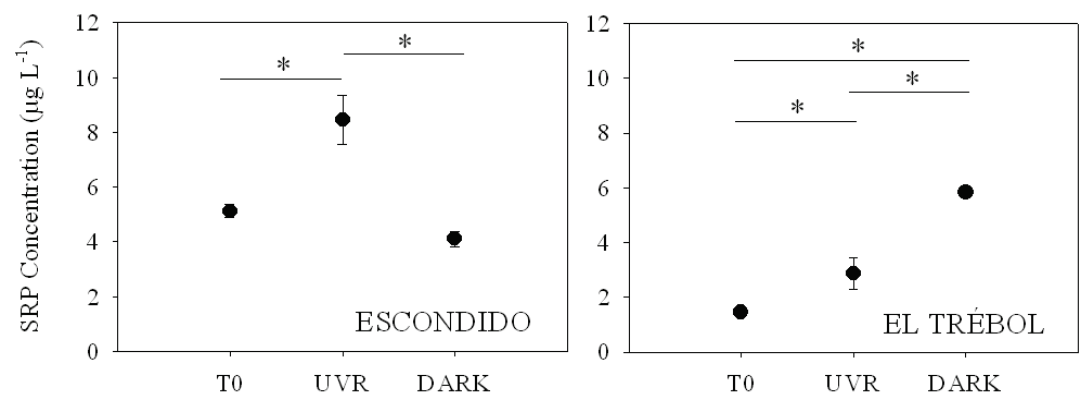

(a)
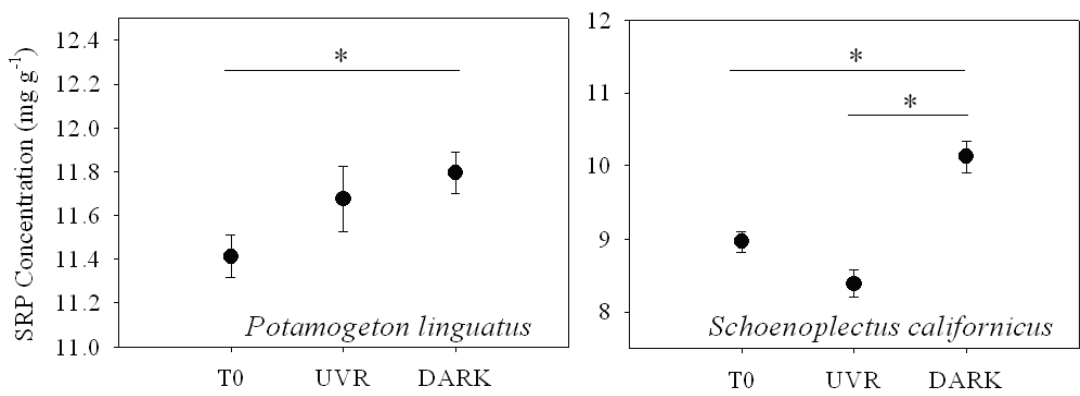

(b)

Fig. 3. Soluble Reactive Phosphorus (SRP) concentration at the initial time (T0), after UVR exposure (UVR), and in the darkness (DARK) in (a) lakes Escondido and El Trébol, and (b) P. linguatus and S. californicus leachates. References: $(*)=$ Significant statistic differences $(P<0.05)$.

observed a slighty less significant positive correlation with $r^{2}=0.718(P<0.001)$, whereas in Lake El Trébol $r^{2}=0.795(P<0.001)$.

\subsection{Soluble Reactive P (SRP) release from DOM exposed to UVR and dark conditions}

At initial time, SRP in lake water showed significant differences between lakes (Two Way ANOVA: Lake Factor, $P<0.001)$. The highest SRP concentration was observed in Lake Escondido $\left(5.1 \mu \mathrm{g} \mathrm{L}^{-1}\right)$, whereas in Lake El Trébol SRP concentration was about $1.45 \mu \mathrm{g}$ $\mathrm{L}^{-1}$ (Fig. 3a). We also observed significant differences between light treatments (UVR or DARK) for both lakes (Two Way ANOVA, Treatment Factor, $P<0.001$ ).
Exposure to UVR of lake water produced a significant increase in SRP concentration in both lakes (Tukey Test: Escondido, $P=0.006$; El Trébol, $P=0.001$ ). However, we observed a different response in the DARK Treatment (Fig. 3a): in Lake Escondido, SRP concentration was similar to that present at initial time (Tukey Test: $P=0.151$ ), while in Lake El Trébol SRP release was significantly higher than T0 (Tukey Test: $P$ $<0.001)$, and the UVR treatment $(P=0.001)$ (Fig. 3a).

Experiment 4 showed that SRP released per gram of plant tissue was significantly different between both macrophytes (Two Way ANOVA: Macrophyte Factor, $P<0.001$ ) (Fig. 3b). At the initial time, $P$. linguatus leachates have significant higher SRP concentration (11.4 $\left.\mathrm{mg} \mathrm{P} \mathrm{g}^{-1}\right)$ than $S$. californicus $\left(9 \mathrm{mg} \mathrm{P} \mathrm{g}^{-1}\right)$ (Tukey 
Test: $P<0.001$ ) (Fig. 3). However, differences in SRP realease were observed between treatments (Two Way ANOVA: Treatment Factor, $P<0.001$ ) (Fig. $3 b$ ). After UVR exposure, $P$. linguatus leachate did not show significant differences (Tukey Test: $P=0.517$ ), while in the DARK treatment a significant increase in SRP release was observed (Tukey Test: $P=0.041$ ). After UVR exposure $S$. californicus leachate showed a significant decrease in SRP (Tukey Test: $P=0.037$ ) (Fig. $3 b$ ) while in DARK treatment, we observed a significant increase in SRP release (Tukey Test: T0 vs OSC, $P$ $<0.001)$.

\section{DISCUSSION}

Solar radiation, particularly in the ultraviolet range (UV-A and UV-B), promotes the phototransformation of the DOM structure, molecular weight and optical properties (Reche et al. 2001; Brinkmann et al. 2003; Obernosterer \& Benner 2004). Our laboratory photodegradation experiments with DOM from lakes Escondido and El Trébol, revealed significant variations in its absorbance spectra and optical features, after UVR exposure. Zagarese et al. (2001) obtained similar results in field experiments in Lake El Trébol where natural lake water was exposed to solar radiation, although in this experiment, vertical water motion exerted an important effect on the net result of photobleaching. However, as our experiments were carried out under laboratory conditions and fixed UVR intensity, the effect of vertical water motion was not considered.

Higher DOM photoreactivity has been observed in lakes located in rocky terrain, which can be explained by a higher influence of autochthonous DOM (with higher photoreactivity), higher mean depth, and differences in the chemistry of the water (Reche et al. 2001). The studied shallow Patagonian lakes are small environments with relatively high organic carbon content (in comparison with the deeper lakes of the area) and have been characterized as humic or slightly humic lakes (Osburn et al. 2001). However, DOM from lake El Trébol seemed to be more reactive than that from Lake Escondido, showing higher changes in the $a_{250}: a_{365}$ ratio and in the spectral slopes after exposure. The higher chlorophyll- $a$ concentrations recorded in the former (Bastidas Navarro et al. 2008, in press), would indicate a higher contribution of autochthonous DOM, and therefore, a more photoreactive DOM.

The morphometry and mix regime of a lake, may significantly affect the volume of water susceptible to react under solar light exposure (Reche et al. 2000; Whitehead et al. 2000). Several studies have indicated that the previous degree of photochemical degradation in natural lake water would have an important effect in the DOC composition and its further capacity to be photodegradated (Morris \& Hargreaves 1997; Reche et al. 1999). In our case, Lake El Trébol has a larger area $\left(0.3 \mathrm{~km}^{2}\right)$ and depth $(12 \mathrm{~m})$ than Lake Escondido (Area:
$0.08 \mathrm{~km}^{2}$ and maximum depth: $8 \mathrm{~m}$ ). It is likely, that DOM from Lake Escondido would have been exposed more time to solar radiation, with a net result of a more refractory DOM with higher degree of aromaticity. Numerous studies have also pointed out that ionic environment $(\mathrm{pH})$ where DOM is dissolved can influence its photoreactivity (Reche et al. 1999; Bertilsson \& Tranvik 2000). Jones et al. (1993) demonstrated that the $\mathrm{pH}$ was an important factor in the SRP release of eutrophic and alkaline lakes. In this sense, acid environment promotes the condensation of humic acids in colloids (Thurman 1985), which seemed to reduce the light access to photoreactive linkages of DOM (Reche et al. 1999). The studied lakes showed very similar $\mathrm{pH}$ values $(7.13 \pm$ 0.06 and $7.04 \pm 0.15$ for Lake Escondido and El Trébol, respectively), thus variations in photoreactivity can not be associated to water $\mathrm{pH}$.

Leachates are chemically heterogeneous compounds with labile and refractory fractions (Peret \& Bianchini 2004). The absorbance spectra obtained from the leachates of $P$. linguatus and $S$. californicus showed maximum absorbances at different wavelengths, suggesting that these macrophytes have differences in their tissue biochemical composition. Submersed macrophytes (Cabomba furca and Utricularia breviscapa) have higher carbon content than emergent ones (Cyperus giganteus, Egeria najas and Oxycaryum cubense) (Bianchini et al. 2008) and Osborne et al. (2007) demonstrated that different macrophyte species (emergent and submersed) produce leachates with differences in major elemental content. Differences in leachates composition could have also influence the net effect of UVR photodegration on both macrophytes: S. californicus leachates exhibited higher photodegradation (measured as the $a_{250}: a_{365}$ ratio) than $P$. linguatus. Anesio et al. (1999) observed similar effects of UVR on DOM of leachates from the emergent macrophytes Phragmites australis, Typha angustifolia and Juncus sp.

On the other hand, DOM may form molecular complex with other elements as $\mathrm{Fe}$ and $\mathrm{P}$. In this sense, it has been observed the formation of a complex DOMFe-P in environments with high concentration of DOM, particularly of allochthonous origin and high molecular weight (Shaw et al. 2000). This complex has received special attention because of the photochemical reduction of $\mathrm{Fe}$, and the subsequent orthophosphate release (Maranger \& Pullin 2003). The generation of DOM-Fe$\mathrm{P}$ complex retains dissolved forms of $\mathrm{P}$, thus, decreasing the availability of this nutrient, causing a resource shortage for the biota (Maranger \& Pullin 2003). The observed variations in SRP concentration between the studied lakes and the response to light treatments is related to the molecular size of DOM. In adition in freshwater environments UVR exposure is an important factor regulating alkaline phosphate activity (Tank et al. 2005). A decrease in alkaline phosphatase activity with UVR exposure is proposed to occur through an indirect 
mechanism whereby photoreduce $\mathrm{Fe}$ binds with and inactivates the enzyme upon oxidization of $\mathrm{Fe}$ by hydrogen peroxide (Scully et al. 2003).

Different macrophyte species allocate P differently in their structural tissues and therefore DOM coming from these species can have different nutrient content (Davis \& Van Der Valk 1983). In this sense, before macrophyte senescence, nutrients may be located in rizomes and other reserving structures, so senescent parts of the macrophyte may have lowered $\mathrm{P}$ content (Osborne \& Kovacic 2007). In our study, P. linguatus leachates have higher P content than S. californicus one suggesting that this submersed macrophyte releases more P to the water column. After UVR exposure, both macrophyte leachates also reacted differently: S. californicus exhibited a decrease in SRP while no significant changes were observed in $P$. linguatus. This would imply that UVR induce some binding of the DOM from $S$. californicus leachates with soluble $\mathrm{P}$, reducing the available P for producers. However, both macrophyte leachates showed the higher $\mathrm{P}$ release in the DARK treatment and, in that sense, Maranger \& Pullin (2003) indicated that DOM of leachates may be reduced in darkness. Our results with $S$. californicus leachates, suggest that in these shallow lakes there would be a double effect of DOM on P, during day, UVR would decrease soluble $\mathrm{P}$, but then during night, dark reduction of Fe (III) associated to DOM would release P. On the other hand, leachates from $P$. linguatus, would only release $\mathrm{P}$ during night without a UVR opposite effect during day.

In conclusion, the obtained results indicated that UVR play a substantial role on optical features and phosphorous release of DOM from lake water and macrophyte leachates.

\section{ACKNOWLEDGMENTS}

This work was supported by FONCyT PICT 200701256 and FONCyT PICT 2007-01258. We thank Dr. Esteban Balseiro for the critical review of this manuscript.

\section{REFERENCES}

American Public Health Association. 2005. Standard methods for the examination of water and wastewater. American Public Health Association, AWWA.

Anesio, A.M., J. Theil-Nielsen \& W. Graneli. 2000. Bacterial growth on photochemically transformed leachates from aquatic and terrestrial primary producers. Microb. Ecol., 40: 200-208.

Anesio, M.A., C.M.T. Denward, L.J. Tranvik \& W. Graneli. 1999. Decrease bacterial growth on vascular plant detritus due to photochemical modification. Aquat. Microb. Ecol., 17: 159-165.

Bastidas Navarro, M., E. Balseiro \& B. Modenutti. 2009. Effect of UVR on Lake Water and Macrophyte Leachates in Shallow Andean-Patagonian Lakes: Bacterial Response to Changes in Optical Features. Photochem. Photobiol., 85: 332-340.
Bastidas Navarro, M., B. Modenutti, C. Callieri, R. Bertoni \& E. Balseiro. (2008). Balance between primary and bacterial production in North Patagonian shallow lakes. Aquat. Ecol.: (in press).

Bertilsson, S. \& J.B. Jones. 2003. Supply of Dissolved Organic Matter to aquatic Ecosystem: autochthonous sources. In: S.E.G. Findlay \& R.L. Sinsabaugh (Eds), Aquatic Ecosystems: Interactivity of Dissolved Organic Matter. Academic Press: 3-24.

Bertilsson, S. \& L.J. Tranvik. 2000. Photochemical transformation of dissolved organic matter in lakes. Limnol. Oceanogr., 45: 753-762.

Bianchini, L.A.B.J., M.B. Cunha-Santino \& A.M. Peret. 2008. Oxygen demand during mineralization of aquatic macrophytes from an oxbow lake. Braz. J. Biol., 68: 61-67.

Brinkmann, T., D. Sartorius \& F.H. Frimmel. 2003. Photobleaching of humic rich dissolved organic matter. Aquat. Sci., 65: 415-424.

Davis, C. \& A. Van Der Valk. 1983. Uptake and release of nutrient by living and decomposing Typha glauca tissues at Eagle Lake, Iowa. Aquat. Bot., 16: 75-89.

Farjalla, V.F., A.M. Anesio, S. Bertilsson \& W. Graneli. 2001. Photchemical reactivity of aquatic macrophyte leachated: abiotic transformation and bacterial response. Aquat. Microb. Ecol., 24: 187-195.

Green, S.A. \& N.V. Blough. 1994. Optical absorption and fluorescence properties of chromophoric dissolved organic matter in natural waters. Limnol. Oceanogr., 39: 19031916.

Helms, J.R., A. Stubbins, J.D. Ritchie, E.C. Minor, D.J. Kieber \& K. Mopper. 2008. Absorption spectral slopes and slope ratios as indicators of molecular weight, source, and photobleaching of chromophoric dissolved organic matter. Limnol. Oceanogr., 53: 955-969.

Jones, H.L.J., B.S.C. Leadbeater \& J.C. Green. 1993. Mixotrophy in marine species of Chrysochromulina (Prymnesiophyceae): Ingestion and digestion of a small gree flagellate. J. Mar. Biol. Assoc. UK, 73: 283-296.

Lewis, W.M. 2002. Yield of nitrogen from minimally disturbed watersheds of the United States. Biogeochemistry, 57: $375-385$

Mans, C., T. Demvard \& L.J. Tranvik. 1998. Effects of solar radiation on aquatic macrophyte litter decomposition. Oikos, 82: 51-58.

Maranger, R. \& M.J. Pullin. 2003. Elemental complexation by Dissolved Organic Matter in lakes: implications for Fe speciation and bioavailability of $\mathrm{Fe}$ and P. In: S.E.G. Findlay \& R.L. Sinsabaugh (Eds), Aquatic ecosystems: interactivity of dissolved organic matter. Academic Press: 186-214.

Morris, D.P. \& B.R. Hargreaves. 1997. The role of photochemical degradation of dissolved organic carbon in regulating the UV transparency of three lakes on the Pocono Plateau. Limnol. Oceanogr., 42: 239-249.

Morris, D.P., H. Zagarese, C.E. Williamson, E.G. Balseiro, B.R. Hargreaves, B. Modenutti, R. Moeller \& C. Queimaliños. 1995. The attenuation of solar UV radiation in lakes and the role of dissolved organic carbon. Limnol. Oceanogr., 40: 1381-1391.

Obernosterer, I. \& R. Benner. 2004. Competition between biological and photochemical processes in the mineralization of dissolved organic carbon. Limnol. Oceanogr., 49: 117-124.

Osborne, L.L. \& D.A. Kovacic. 2007. Riparian vegetated buffer strips in water-quality restoration and stream management. Freshwat. Biol., 52: 243-258.

Osburn, C.L., H.E. Zagarese, D.P. Morris, B.R. Hargreaves \& W.E. Cravero. 2001. Calculation of spectral weighting functions for the solar photobleaching of chromophoric dissolved organic matter in temperate lakes. Limnol. Oceanogr., 46: 1455-1467. 
Paruelo, J.M., A. Beltran, E. Jobbágy, O. Sala \& R. Golluscio. 1998. The climate of Patagonia: general patterns and controls on biotics processes. Ecol. Austral., 8: 85-101.

Peret, A. \& I. Bianchini. 2004. Stoichiometry of aerobic mineralization $(\mathrm{O} / \mathrm{C})$ of aquatic macrophytes leachate from a tropical lagoon (Sao Paulo -Brazil). Hydrobiologia, 528: $167-178$.

Perez, M.T. \& R. Sommaruga. 2006. Differential effect of algal- and soil-derived dissolved organic matter on alpine lake bacterial community composition and activity. Limnol. Oceanogr., 51: 2527-2537.

Qualls, R.G. \& C.J. Richardson. 2003. Factors controlling concentration, export, and decomposition of dissolved organic nutrients in the Everglades of Florida. Biogeochemistry, 62: 197-229.

Reche, I., M.L. Pace \& J.J. Cole. 1999. Relationship of trophic and chemical conditions to photobleaching of dissolved organic matter in lake ecosystems. Biogeochemistry, 44: 259-280.

Reche, I., M.L. Pace \& J.J. Cole. 2000. Modeled Effects of Dissolved Organic Carbon and Solar Spectra on Photobleaching in Lake Ecosystems. Ecosystems, 3: 419-432.

Reche, I., E. Pulido-Villena, J.M. Conde-Porcuna \& P. Carrillo. 2001. Photoreactivity of dissolved organic matter from high-mountain lakes of Sierra Nevada, Spain. Arct. Antarct. Alp. Res., 33: 426-434.

Rogora, M., J. Massaferro, A. Marchetto, G. Tartari \& R. Mosello. 2008. The water chemistry of some shallow lakes in Northern Patagonia and their nitrogen status in comparison with remote lakes in different regions of the globe. $J$. Limnol., 67: 75-56.

Schindler, D.W. \& P.J. Curtis. 1997. The role of DOC in protecting freshwaters subjected to climatic warming and acidification from UV exposure. Biogeochemistry, 36: 1-8.

Scully, N.M., L.J. Tranvik \& W.J. Cooper. 2003. Photochemical effects on the interaction of enzymes and dissolved organic matter in natural waters. Limnol. Oceanogr., 48: 1818-1824.

Received: August 2009

Accepted: November 2009
Shaw, P.J., R.I. Jones \& H.D. Haan. 2000. The influence of humic substances on the molecular weight distributions of phosphate and iron in epilimnetic lake waters. Freshwat. Biol., 45: 393-393.

Shick, J.M., S. Romainelioud, C. Ferrierpages \& J.P. Gattuso. 1999. Ultraviolet-B radiation stimulates shikimate pathway-dependent accumulation of mycosporine-like amino acids in the coral Stylophora pistillata despite decreases in its population of symbiotic dinoflagellates. Limnol. Oceanogr., 44: 1667-1682.

Strober, Q., R. Jones \& D. Schmidt. 1995. Ultratrace level mercury in the everglades ecosystem: a multi-media cannal pilot study. Water Air Soil Pollut., 80: 991-1001.

Tank, S.E., M.A. Xenopoulos \& L.L. Hendzel. 2005. Effect of ultraviolet radiation on alkaline phosphatase activity and planktonic phosphorus acquisition in Canadian boreal shield lakes. Limnol. Oceanogr., 50: 1345-1351.

Thurman, P.C. 1985. Wastewater treatment plants. Landscape Architecture, 75: 52-54.

Vernet, M. 2006. Introduction: Enhanced UV-B radiation in natural ecosystems as an added perturbation due to ozone depletion. Photochem. Photobiol., 82: 831-833.

Villafañe, V., E.W. Helbling \& H.E. Zagarese. 2001. Solar ultraviolet radiation and its impact on aquatic systems of Patagonia, South America. Ambio, 30: 112-117.

Wetzel, R. G. 2001. Lymnology Lake and River Ecosystems. Academic Press.

Whitehead, R.F., S. Demora, S. Demers, M. Gosselin, P. Monfort \& B. Mostajir. 2000. Interactions of ultraviolet-B radiation, mixing, and biological activity on photobleaching of natural chromophoric dissolved organic matter: a mesocosm study. Limnol. Oceanogr., 45: 278-291.

Zagarese, H.E., M. Diaz, F. Pedrozo, M. Ferraro, W. Cravero \& B. Tartarotti. 2001. Photodegradation of natural organic matter exposed to fluctuating levels of solar radiation. $J$. Photochem. Photobiol. B: Biol., 61: 35-45.

Zepp, R.G., T.V. Callaghan \& D.J. Erickson III. 2003. Interactive effects of ozone depletion and climate change on biogeochemical cycles. Photochem. Photobiol. Sci., 2: 51-61. 